\title{
地盤改良技術に関する最新動向 Recent Trends In Ground Improvement Technologies
}

2011 年 3 月 11 日に東北地方太平洋沖地震と大津波が東北・関東地方を襲い，甚大な被害が発生した．液状化や宅地 地盤の崩壊など地盤に関わる被害も深刻で, 専門家・行政のみならず一般市民にも「地盤」ならびに地盤を改善する「地 盤改良」が注目されるところとなっている．地盤改良が施されたことにより被害が防止軽減できた事例も多くみられ，地 盤改良の役割が再認識されるとともに進化が求められている.

地盤環境問題についても近年様々な動きがあり，特に 2003 年の土䁃污染対策法の施行に伴い土䁃調査や対策工事が 増加している。土地取引等に伴い判明する土壌污染は，時に社会問題化するなどその対応を難しくしているし，建設工 事で発生する掘削土砂に自然由来の七素や鉛などが基準を超過して含まれることから，対策に多額のコストと労力を費 やしている例もある。したがって, 安心・安全の確立とともに地盤環境污染の適切な評価と合理的な対策が求められて いる.

地盤改良部門委員会は昭和 37 年に土質安定材料委員会として発足して以来 50 年にわたって地盤改良に関する広範な 課題についての研究調査活動に取り組んできた。その一つが環境地盤工学に関わる研究であり, 最近では地盤污染の対策 工法や浄化工法に関する新しい地盤改良工法の開発やその適用などがあげられる。2009 年には「地盤環境研究会」を設 け，地盤污染への封じ込め技術，自然由来の重金属を含有する発生土へと対応の二つの主要課題に取り組んできた。本講 座の前半 2 回「1. 掘削物の有効利用と自然由来の重金属」「2. 地盤污染の封じ込め」は当研究会の成果に基づいている.

地盤改良は大規模構造物のみに適用されるものではない. 東日本大震災の宅地被害でもみられたように，小規模住宅 に打いても地盤問題に適切に対処することが重要である。2006 年に活動を始めた「地盤改良の建築基礎への適用に関す る研究会」は，穴の成果物として「実務者のための戸建住宅の地盤改良・補強工法一考え方から適用まで」を震災に先 立つ 2010 年に世に問うた。本講座の「3. 地震による地盤災害と地盤改良技術」は，東日本大震災の被害状況を当研究 会の知見も踏まえて解説したものである。一方，「4. 自然災害からの復興と地盤改良技術」は，被災地の復旧復興におい て適用される地盤改良技術（災害廃棄物处理と復興資材への活用を含む）についてその方向性も含めて解説している。

このように本講座 4 回で取り扱うテーマは，地盤環境と防災・災害復興という広範なものとなっている。しかしこれ らは本来別々のものではなく，強勒な社会基盤を形成・維持していく上で一体で考えていくべきものである，そのよう な視点で本講座を打読み頂ければ幸いである。

\section{1. 掘削物の有効利用と自然由来の重金属 ${ }^{\dagger}$ 乾徹 ${ }^{*}$ 大 将 $^{* *}$ 三浦 俊 彦 ${ }^{* * *}$ I : Geotechnical Utilization of Excavated Materials Containing Natural-Derived Heavy Metals}

by

Toru InuI ${ }^{*}$, Sho Oyama ${ }^{* *}$ and Toshihiko Mivra ${ }^{* * *}$

Key words : Excavated rock and soil, Leaching, Heavy metals

\section{1 緒}

我が国には熱水変質の影響を受けた火山岩類や海成泥 質堆積物などが広く分布しており，これらの中には自然 的原因で重金属等を含有しているものが多い，そのため， 建設工事で掘削した岩石や土砂から環境基準を上回る濃 度で重金属等が溶出する事例が全国各地で報告されてい
る. ${ }^{1) \sim 5)}$ 法律的には，平成 22 年 4 月以前は自然的原因に よる重金属等が含まれる土䁃については土䁃污染対策法 の対象外とされてきたが，平成 22 年 4 月の土䁃污染対 策法の改正, 打よび平成 23 年 7 月の施行規則の一部改 正により, 自然的原因であっても, 法に基づいた対応が 必要となった。一方, 土蚺污染対策法の対象外となって

$\dagger$ 原稿受理 平成 24 年 7 月 10 日 Received July 10, 2012 @ 2013 The Society of Materials Science, Japan

* 正 会 員 京都大学大学院地球環境学堂 干606-8501 京都市左京区吉田本町, Graduate School of Global Environmental Studies, Kyoto Univ., Sakyo-ku, Kyoto, 606-8501

** 賛助会員 鴻池組(森) ₹136-8880 東京都江東区南砂, Konoike Construction, Co., Ltd., Koto-ku, Tokyo, 136-8880

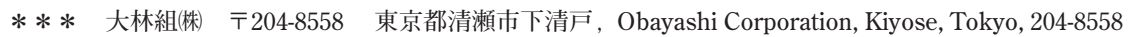


いる粒径 $2 \mathrm{~mm}$ 以上の岩石等の掘削物についても，建設工 事の実施によって新たに周辺環境への重金属等の拡散が 生じないように適切な対応を取ることが求められている。

本稿では，はじめに自然由来の重金属等による問題の 概況と重金属等の溶出特性の概要，および対応・対策の 考え方をとりまとめる。続いて，自然由来の重金属等を 含む掘削物の対策に用いられる各種技術のうち，「地盤改 良技術」を適用・応用している(1)覆土，(2)不溶化，(3)反 応層・遮水層, の 3 つの技術について, 研究開発や現場 適用の状況を文献レビューに基づいて解説する。これら の技術は，雨水浸透の防止，重金属等の溶出抑制，溶出 した重金属等の捕捉によって掘削物に含有される重金属 等の拡散を防止する技術である。拡散防止技術は污染物 質を除去，分解する技術ではないが，地下水等摂取によ るリスクを低減する上では非常に有効であり，比較的低 コストであることから，その普及が期待される。その一 方で，有害物質が掘削物中に残存することから各対策に よる拡散防止性能を適切にかつ長期的な観点で評価する ことが重要となる。

\section{2 自然由来重金属等による問題の概要}

土壌污染対策法は，土壌污染に伴う人の健康への影響 を防止することを目的としており，対象とする有害物 （特定有害物質）として 25 物質が指定されている。特定 有害物質の多くは人工的に製造された化学物質であるが， 人の健康に影響を及ぼすという観点から天然に存在する 8 物質（カドミウム, 鉛, 六価クロム, 砒素, 水銀, セ レン，ふっ素，ほう素，およびこれらの化合物）も含ま れている。地殻を構成する岩石・土壤は普遍的に天然の 状態でこれらの物質を含んでおり，上記の 8 物質を「自 然由来重金属等」と称することが多い，岩石・土壤には 銅などの他の重金属も含まれていること，確素は亜金属 であり，ふっ素，ほう素も金属ではないことから，上記 の定義に違和感を持たれるかもしれない.しかしながら， 実際の建設現場においては土㙵污染対策法の対象となる 物質が問題になることから，上記の 8 物質を「自然由来 の重金属等」と総称することが多く，本稿でも同様に定 義する.

自然由来重金属等の地殼中含有量に関する各種調査結 果をまとめたものを表 1 に示す. ${ }^{6)}$ 地殻の組成としては， Clark \& Washington (1924) が数千に及ぶ火成岩の元素 分析から平均值を提案したクラーク数 ${ }^{7)}$ がよく知られて いるが，火山作用や堆積作用などの影響を受け，これら の重金属等が濃集したり，溶出しやすい地域，地層が存 在する。例えば，日本については砒素や鉛の濃度が世界 的な平均值より高くなっている.

自然由来重金属等による大規模な地下水污染事例とし ては，バングラディシュ，インド西ベンガル，中国，南 米大陸等に扎いて砒素を含む地下水を長期に渡って飲用 し，健康被害が生じている例が知られている. ${ }^{8)}$ 我が国で は大規模な健康被害は報告されていないが，地下水中に 扎いて環境基準值を超過する事例は以下の通り報告され ている，環境省による平成 22 年度地下水質測定結果 ${ }^{9)}$ に よると, 上記の 8 物質による環境基準超過事例 1,247 件 のうち約 $68 \%$ の 852 件が自然的原因によるものとされて いる，特に，砒素，水銀，ふっ素，ほう素に関しては， 自然由来による超過事例が数多く報告されている.

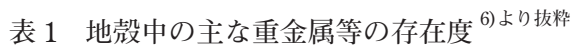

\begin{tabular}{|c|c|c|c|c|}
\hline 元素 & $\begin{array}{l}\text { 地殼の平均値 } \\
\text { (クラーク数) }\end{array}$ & $\begin{array}{l}\text { 大陸地殼 } \\
\text { の元素量 }\end{array}$ & $\begin{array}{l}\text { 日本列島上部 } \\
\text { 地殼の平均値 }\end{array}$ & $\begin{array}{l}\text { 日本の河川堆 } \\
\text { 積物の平均值 }\end{array}$ \\
\hline カガミウム & 0.2 & 0.098 & & 0.158 \\
\hline クロム & 100 & 185 & 84 & 65.2 \\
\hline 吪素 & 1.8 & 1 & $6.5-7.1$ & 9.32 \\
\hline 鉛 & 13 & 8 & 16.9 & 23.1 \\
\hline セレン & 0.05 & 0.05 & - & - \\
\hline ふつ素 & 625 & 625 & - & - \\
\hline ほう素 & 10 & 10 & - & - \\
\hline 水銀 & 0.08 & 0.08 & - & 0.054 \\
\hline
\end{tabular}

一方，岩石や堆積物における自然由来の重金属等によ る環境基準の超過事例は，砒素，セレン，鉛，フッ素，

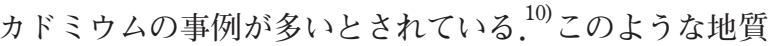
の周辺地域で掘削工事が行われる場合には，掘削物から 基準值以上の重金属等が溶出することが多く，適切な対 策，管理が重要となる，表 2 に主な自然由来の重金属等 を含む掘削物への対応事例をとりまとめる，なお，表 2 の 例は一例であり，さらなる事例については他の文献 2), 11) を参照されたい。これらの事例をみると，大規模工事の 場合は発生量が多いことから，道路盛土路体や管理型土 捨場に封じ込める対策が大半となっている。これは，重 金属等の拡散を防止すること，打よび主要な重金属等の 溶出原因となる硫化鉱物の酸化を抑制する観点から雨水 や空気の侵入を防ぐことに主眼が扔かれているためであ る。しかしながら近年ではセメント固化や天然資材によ る重金属等に対する吸着機能を活用した方法も提案され ており，地盤改良技術の一層の活用が期待されている。

\section{3 自然由来重金属等の溶出特性とその評価 \\ $3 \cdot 1$ 砒素の溶出特性}

本節では，最も事例の多い砒素を対象として，その溶 出特性を概観する。

砒素は地層・岩盤中に执いては毒性が高い三価の状態 で存在するが，表層土壌や水中では酸化され五価の状態 で存在することが多い，特に，熱水性鉱床中や堆積岩等 に含まれる黄鉄鉱（パイライト）をはじめとする硫化鉱 物中に硫砣鉄鉱 $(\mathrm{FeAsS})$ などとして数万 $\mathrm{ppm}$ の濃度て

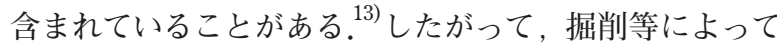
硫化鉱物が酸化分解すると砒酸（酸化的環境）や亜砒酸

\section{表 2 大規模工事に伴う自然由来重金属類への対応例}

\begin{tabular}{|c|c|c|c|}
\hline 現場 & 対象元素, 地質 & 対策概要 & 文献 \\
\hline $\begin{array}{l}\text { 旭川紋別自 } \\
\text { 動車道中越 } \\
\text { トンネル }\end{array}$ & 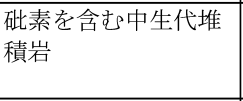 & $\begin{array}{l}\text { 底面遮水+仮置き, 盛土 } \\
\text { 内への遮水シート封じ } \\
\text { 込め, セメント固化 }\end{array}$ & $\begin{array}{l}\text { 藤井ら } \\
(2005)^{12)}\end{array}$ \\
\hline $\begin{array}{l}\text { 東北新幹線 } \\
\text { 八甲田トン } \\
\text { ネル }\end{array}$ & $\begin{array}{l}\text { 閃緑岩, 安山岩等の貫 } \\
\text { 入岩体の接触部付近 } \\
\text { や鉱脈の周辺部に位 } \\
\text { 置する鉱化変質岩. 砒 } \\
\text { 素, 鉛, カドミウム, } \\
\text { セレン. }\end{array}$ & $\begin{array}{l}\text { 管理型土捨場（遮水シー } \\
\text { トによる封じ込め）への } \\
\text { 処分 }\end{array}$ & \begin{tabular}{|l|} 
服部ら \\
$(2003)^{1)}$
\end{tabular} \\
\hline $\begin{array}{l}\text { 一般国道 } 289 \\
\text { 号甲子トン } \\
\text { ネル }\end{array}$ & $\begin{array}{l}\text { 更新統と新第三紀の } \\
\text { 玄武岩質岩, 安山岩 } \\
\text { 等. 鉛, 砒素, セレン. }\end{array}$ & $\begin{array}{l}\text { 道路盛土工事の路体に } \\
\text { 二重遮水シートによる } \\
\text { 封じ込め }\end{array}$ & $\begin{array}{l}\text { 奥村ら } \\
(2007)^{2)}\end{array}$ \\
\hline $\begin{array}{l}\text { 仙台市高速 } \\
\text { 鉄道東西線 }\end{array}$ & $\begin{array}{l}\text { 新第三紀鮮新世竜の } \\
\text { ロ層, 砒素, カドミウ } \\
\text { ム, フッ素, 鉛, セレ } \\
\text { ン. }\end{array}$ & $\begin{array}{l}\text { 盛土の一部として利用 } \\
\text { し, 覆土. 排水処理施設. }\end{array}$ & $\begin{array}{l}\text { 谷畑ら } \\
(2010)^{3)}\end{array}$ \\
\hline $\begin{array}{l}\text { 新東名高速 } \\
\text { 道路愛知県 } \\
\text { 区間 }\end{array}$ & $\begin{array}{l}\text { 変成岩 (片麻岩). 砒 } \\
\text { 素. }\end{array}$ & $\begin{array}{l}\text { 道路盛土内に遮水シー } \\
\text { 卜, 粘土層で封じ込め. } \\
\text { セメント改良. }\end{array}$ & $\begin{array}{l}\text { 和崎ら } \\
(2012)^{5}\end{array}$ \\
\hline
\end{tabular}


（還元的環境）として溶存することになる．別の溶出メカ ニズムとしては，堆積層中で水酸化鉄，粘土鉱物，有機 物等に吸着されて存在する砒素が，酸化一還元状態や $\mathrm{pH}$ の変化によって溶出することがあり，我が国でもいく つかの事例が報告されている. ${ }^{14)}$ 具体的には，地下水の還 元化による脱着, 還元的環境における鉄水酸化物の分解 が溶出の原因として挙げられる。

\section{$3 \cdot 2$ 建設工事による重金属の形態変化}

建設工事の実施による砒素の溶出挙動への具体的な影 響としては，掘削による細粒化，雨水や空気への曝露， 酸化や風化の進行等が挙げられるが詳細については既往 の報告 ${ }^{15)}$ を参考にされたい.

重金属等の溶解性は存在形態によって影響を受けるこ とはよく知られている。表 3 に重金属の存在形態の代表 的な分画法を示す. ${ }^{16)}$ 和田 $(2010)^{17)}$ も指摘しているよう に，これらの方法は土壌中の重金属の形態を厳密に求め るものではないが，重金属の溶出のし易さ，後述する不 溶化や吸着のメカニズムを知る上で有用な試験方法とな る。例えば，小川ら (2012) ${ }^{18)}$ は還元的環境にある堆積岩 や堆積物が好気的環境に置かれ，硫化鉱物の分解が生じ たときの重金属等の存在形態変化を調査している。ガ ミウムについては, 硫化物態が酸化や風化によって水溶 性や交換態に変化して非常に溶出しやすくなるのに対し， 硫化物態の砒素はリン酸交換態や酸化物態への形態変化 となるため, 顕著な溶出は見られないことを示している. 田本ら $(2009)^{19)}$ も同様に風化による影響を調査し, 砒素 は風化作用を受けても比較的溶出しにくいが，セレンに ついては風化により溶出しやすい形態に変化することを 示している.

砒素の溶出が硫化鉱物の分解時においても比較的抑制 されるメカニズムは以下の通りと考えられる. ${ }^{15)}$ 砒素は水 溶液中で酸素との化合物である砒酸イオン $\left(\mathrm{H}_{2} \mathrm{AsO}_{4}{ }^{-}\right.$, $\mathrm{HAsO}_{4}{ }^{2-}$ 等) として存在している場合が多い.ここで例え ば，黄鉄鉱が化学変化して生じた硫酸第二鉄により式 (1) の反応が進み水酸化第二鉄が生成された場合, $\mathrm{Fe}(\mathrm{OH})_{3}$ は砒酸イオンを吸着しやすいため, 難溶性となり沈殿する.

$$
\mathrm{Fe}_{2}\left(\mathrm{SO}_{4}\right)_{3}+6 \mathrm{H}_{2} \mathrm{O} \rightarrow 2 \mathrm{Fe}(\mathrm{OH})_{3}+6 \mathrm{H}_{2} \mathrm{SO}_{4}
$$

さらには，䃂酸イオンに関しては式 (2)の反応が進み, $\mathrm{FeAsO}_{4}$ 等の鉄酸化物態として沈殿が生じ, 特に $\mathrm{pH}$ が低 い条件においてはこの形態が維持されることも知られて いる。

$$
2 \mathrm{H}_{3} \mathrm{AsO}_{4}+\mathrm{Fe}_{2}\left(\mathrm{SO}_{4}\right)_{3} \rightarrow 2 \mathrm{FeAsO}_{4}+3 \mathrm{H}_{2} \mathrm{SO}_{4}
$$

\begin{tabular}{|c|c|c|}
\hline 形態 & 抽出溶媒 & 形態の特徵 \\
\hline 1. イオン交換態 & $\begin{array}{c}\text { 塩化マグネシウムまた } \\
\text { は酢酸 ナトリウム } \\
\text { (pH8.2) }\end{array}$ & $\begin{array}{l}\text { イオン交換による溶出する } \\
\text { 形態 }\end{array}$ \\
\hline 2. 炭酸塩態 & 酢酸ナトリウム $(\mathrm{pH} 5.0)$ & $\begin{array}{l}\text { イオンとして存在するがイ } \\
\text { オン交換態ほど容易には溶 } \\
\text { 出しない形態 }\end{array}$ \\
\hline $\begin{array}{l}\text { 3. 鉄・マンガン酸 } \\
\text { 化物態 }\end{array}$ & $\begin{array}{l}\text { 亜二チオン酸ナトリウ } \\
\text { ム, クエン酸イオン, ヒ } \\
\text { ドロキシルアミン }\end{array}$ & $\begin{array}{l}\text { 鉄やマンガン酸化物に吸着 } \\
\text { している形態 (酸素存在下で } \\
\text { は溶出しない) }\end{array}$ \\
\hline $\begin{array}{l}\text { 4. 有機物結合態 } \\
\text { 5. 残渣 }\end{array}$ & $\begin{array}{l}\text { 硝酸, 過酸化水素水 } \\
\text { 濃硝酸で加熱分解 }\end{array}$ & $\begin{array}{l}\text { 有機物と結合 } \\
\text { 鉱物, 硫化物などとして存在 }\end{array}$ \\
\hline
\end{tabular}

表 3 重金属の存在形態の類推例 ${ }^{16)}$

\section{$3 \cdot 3$ 長期的な溶出特性の評価}

自然由来の重金属等を含む掘削物の溶出特性を推定す る環境影響試験法の目的として, 対策の要否を判定するこ とはもちろんのこと，対策を行った場合の溶出源評価と しての重要性も高い. 自然由来の重金属等は前節に示した ように，掘削に伴う水や空気との接触状態の変化や酸化 によって溶出特性が大きく変化することが知られており, このことに配慮して適切な試験を採用する必要がある。

表 ${ }^{15)}$ に自然由来の重金属等を含有する掘削物を対象 に実施される主な環境影響試験法をとりまとめる。前述 したように酸性化が溶出挙動に及ぼす影響が大きいこと から, 酸性化ポテンシャルやその程度について $\mathrm{pH}$ 試験 や化学組成試験から判断するのが大きな特徴になってい る. 酸性化のしやすさの評価方法としては, 「過酸化水素 水を用いる $\mathrm{pH}$ 試験」に準じた酸性化可能性試験が適用 され，本試験法に準じて強制的に酸性化させた場合に $\mathrm{pH} \leq 3.5$ となる岩石については, 長期的に酸性化可能性 があると判断する。上記方法では，過酸化水素水濃度は $30 \%$ として規定されているが，表 4 にも記載しているよ うに過酸化水素水濃度は様々な濃度で検討が行われてい る。図 1 は乾ら $(2012)^{20)}$ による $3 \%$ と $30 \%$ 濃度の過酸化 水素水で強制酸化させた場合の 5 種類の岩石試料の $\mathrm{pH}$ を示す。岩石の種類によって $\mathrm{pH}$ の低下の程度が異なり， 図 1 中の泥岩 2 は $30 \%$ 過酸化水素水による酸性化作用を 受けると $\mathrm{pH}$ が 3.5 以下となる一方で, $3 \%$ 過酸化水素水 に対しては中性を維持している。 これらの岩石試料を 2 年 以上に渡り屋外曝露した際の $\mathrm{pH}$ 等の変化と比較すると, 2 年程度の屋外での酸性化は $3 \%$ 過酸化水素水による室内 試験での強制酸性化と概ね同程度であるとしている.よつ て, 掘削物の仮置きや盛土への埋立の期間中の酸性化で あれば， $3 \%$ 過酸化水素水で概ね再現できるといえる.

表 4 に記載している, 屋外曝露試験やライシメータ試 験といった現場条件に近い状態での試験（実現象再現試 験）は比較的精度良く溶出挙動を推定することができる が, 時間や費用を要するため実施が困難である。したがつ て, 室内で短期間に実施できる評価試験の結果と実現象 再現試験結果を比較・検証することにより，簡便な評価 試験による長期溶出挙動の推定法を確立することが重要 となる。

図 $2^{20}$ に砒素を含有する酸性安山岩 (図 1 中の安山岩 試料）を対象に実施した， 2 年以上の長期屋外曝露試験， 岩塊を対象とした 28 日間のタンクリーチング試験， $2 \mathrm{~mm}$ 以下に破砕した試料を対象としたバッチ溶出試験 (液固比 10 ），30\% 過酸化水素水打よび $3 \%$ 過酸化水素水 を用いたバッチ溶出試験（液固比 10）の結果を比較した ものを示す。本困では異なる条件で実施した試験結果を 相互に比較するため，試験中に岩石試料に接触させた水 量（単位質量の岩石あたりの水量（液固比）に換算, $\mathrm{L} / \mathrm{kg}$ ） と，単位質量の岩石からの砒素溶出量の累積値 $(\mathrm{mg} / \mathrm{kg})$ の関係で整理している. 液固比 10 の時点での 各試験の溶出量を比較すると, バッチ溶出試験結果と雨 水曝露試験の累積溶出量は同等であり，過酸化水素水を 用いたバッチ溶出試験では過大に溶出量を評価している. 本試料は酸性岩であるが, 図 1 に示すように, 高濃度の 過酸化水素水に対してさらに $\mathrm{pH}$ が低下している。よっ て，長期的にさらなる酸性化可能性を示す試料であり， 
表 4 環境影響試験法の分類 ${ }^{15)}$

\begin{tabular}{|c|c|c|c|}
\hline 分析対象 & 分類 & 主な試験方法 & 備考 \\
\hline \multirow{4}{*}{ 重金属類 } & 公定試験 & $\begin{array}{l}\text { 土㙵溶出量試験 } \\
\text { 土㙥含有量試験 }\end{array}$ & $\begin{array}{l}\text { - 平成 } 15 \text { 年 } 3 \text { 月環境省告示第 } 18 \text { 号 } \\
\text { - 平成 } 15 \text { 年 } 3 \text { 月環境省告示第 } 19 \text { 号 }\end{array}$ \\
\hline & 全含有量試験 & $\begin{array}{l}\text { 蛍光 X 線分析法 } \\
\text { 湿式分析法 }\end{array}$ & $\begin{array}{l}\text { - 砒素, 鉛についてはJIS 規格有 } \\
\text { • 底質調査法, 土壌環境分析法等 } \\
\end{array}$ \\
\hline & 存在形態分析試験 & 分別抽出法 & ・各種抽出操作が普及している \\
\hline & 溶出試験 & $\begin{array}{l}\text { バッチ試験 } \\
\text { カラム試験 } \\
\text { タンクリーチング試験 } \\
\text { ライシメータ試験 } \\
\text { 屋外曝露試験 }\end{array}$ & $\begin{array}{l}\mathrm{pH} \text { や酸性化等が溶出挙動及ぼす影響の調 } \\
\text { 查を併せて行うため, 対象物質の溶出濃度 } \\
\text { に加えて, 水温, 水量, } \mathrm{pH} \text {, 電気伝導度, } \\
\text { 酸化還元電位等を計測する必要がある。 }\end{array}$ \\
\hline \multirow{2}{*}{ 酸性化 } & $\mathrm{pH}$ 試験 & $\begin{array}{c}\text { 過酸化水素水を用いる } \mathrm{pH} \text { 試験 } \\
\text { 溶出水の } \mathrm{pH} \\
\end{array}$ & $\begin{array}{l}\text { ·過酸化水素水濃度は複数の事例有。 } \\
\text { • 主要イオン分析を行う場合もある。 }\end{array}$ \\
\hline & 化学組成試験 & $\begin{array}{c}\text { 硫黄含有量 } \\
\text { 硫黄／カルシウム比 }\end{array}$ & ・帯磁率を指標とする事例もある。 \\
\hline
\end{tabular}

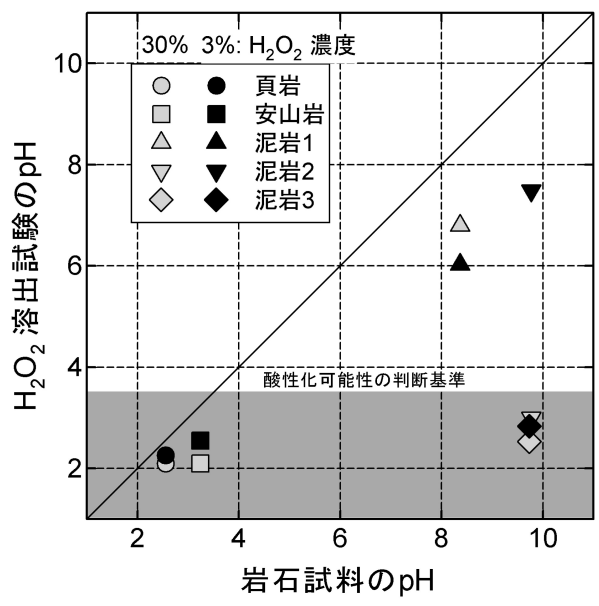

図 1 岩石試料の過酸化水素水による酸性化時の $\mathrm{pH}^{20}$

雨水曝露試験において液固比 10 以降（2 年弱経過時点） でプロットの勾配が急になっている。これは，時間の経 過によって低濃度ではあるが，溶出濃度が上昇したこと を示して打り，過酸化水素水を用いたバッチ溶出試験に よって溶出量が増加する傾向と一致するものであり，簡 便な試験による長期溶出挙動の評価可能性を示している.

自然由来重金属等の溶出特性の評価は依然として多く の課題は残されているが，これらの知見を蓄積すること によって実務に反映し，安全かつ合理的な対応の実施に 貢献することが重要である。

\section{4 有効利用のための対策と地盤改良技術の適用}

\section{$4 \cdot 1$ 対策の基本的考元方}

第 3 章に示した溶出特性の評価の結果, 対策が必要と なった場合，土壌污染対策法の対象になるか否かで対策 の考え方が大きく異なる。土堙污染対策法に準じた対策 を原位置において行う場合には，舗装，盛土等による直 接摂取による影響の防止，および原位置・遮水工封じ込 め (不溶化後封じ込めを含む), 遮断工封じ込め, 地下 水污染の拡大の防止, もしくは不溶化を行い, 溶出した 重金属等によって污染された地下水等の撕取による影響 の防止を図ることが現実的である.

一方，岩石等の土壌污染対策法の対象にならない場合 には, 直接摂取や地下水等の摂取による影響の防止を行っ た上で盛土構造物等として有効利用が可能になると考え られる。しかしながら，有効利用をした際にも直接摂取 や地下水等の損取による影響が許容目標以下であること

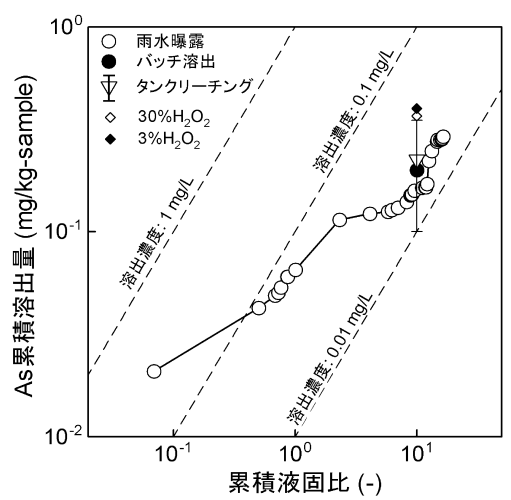

図 2 様々な試験方法による溶出挙動の比較 ${ }^{20}$

が求められる．許容目標の定義は事例によって異なると 考えられるが，例えば国土交通省 (2010) ${ }^{6)}$ は，地下水等 の摂取に関する目標を「敷地境界もしくは保全対象近傍 に扎いて地下水環境基準もしくは地下水のバックグラウ ンド值のうち高い方を超過しないこと」としている。

表 5 に地下水等の摂取による影響を防止する対策の考 え方を示す．前章に示したように，自然由来重金属等の 長期溶出挙動を定量的に精度良く評価することは難しい。 そのため, 溶出を引き起こす要因の遮断（雨水浸透の防 止），溶出低減（不溶化処理），溶出した重金属等の捕 捉・流出防止（反応層の設置，浸出水回収）の 3 つの観 点からの対応が重要となる。さらに結果として重金属等 の流出量が非常に小さくなれば自然減衰 (Natural

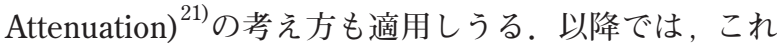

表 5 地下水の撕取による影響を防止する措置の内容

\begin{tabular}{|c|c|c|}
\hline 対応 & 効果 & $\begin{array}{l}\text { 具体的な内容 } \\
\text { (複数併用可) }\end{array}$ \\
\hline \multirow{4}{*}{$\begin{array}{l}\text { 土㙥污染対策法隻 } \\
\text { じた原位置での対 } \\
\text { 策 }\end{array}$} & \multirow{4}{*}{$\begin{array}{l}\text { 地下水等の摂取に } \\
\text { よる影響の防止 }\end{array}$} & $\begin{array}{l}\text { 原位置封じ込め・遮水工封じ込 } \\
\text { め(不溶化後封じ込めを含む) }\end{array}$ \\
\hline & & 遮断工封じ込め \\
\hline & & 地下水污染の拡大の防止 \\
\hline & & $\begin{array}{l}\text { 不溶化（第二溶出量基準適合 } \\
\text { 時） }\end{array}$ \\
\hline \multirow{5}{*}{$\begin{array}{l}\text { リスク評価による } \\
\text { 選定・設計可能な対 } \\
\text { 策 }\end{array}$} & \multirow{2}{*}{$\begin{array}{l}\text { (1) 雨水・地下水の } \\
\text { 浸透, および浸出水 } \\
\text { の発生防止 }\end{array}$} & 粘性土等による覆土・敷土 \\
\hline & & 転圧による透水性の低下 \\
\hline & \begin{tabular}{|l} 
(2) 重金属等の溶出 \\
低減 \\
\end{tabular} & 不溶化処理 \\
\hline & \multirow{2}{*}{ (3) 重金属等の捕捉 } & 反応 (吸着) 層 \\
\hline & & 浸出水回収, 処理 \\
\hline
\end{tabular}


らの対策技術の中で地盤改良技術との関連が深い, (1)雨 水浸透や酸化防止を考慮した対策盛土，(2)自然由来重金 属等を対象とする不溶化処理， (3)反応 (吸着) 層・遮水 層について最近の事例を紹介する。

\section{$4 \cdot 2$ 対策盛土の事例}

表 2 に示すように，道路盛土内への封じ込めは自然由 来重金属等を含有する掘削物の有効利用手法としては最 も適用事例が多い手法である.

盛土による対策効果としては，遮水構造による雨水や 地下水浸透の防止が第一に挙げられる。ただし, 覆土の 雨水浸透防止能力や構造に関する設計基準が整備されて いないことから，遮水構造としては遮水シートの適用事例 が最も多い，遮水シート以外の事例としては，仙台市高 速鉄道東西線の対策盛土の事例 ${ }^{3)}$ が挙げられる。本事例 では表層には覆土もしくは前面盛土の土構造物のみ施工 しているが，掘削物層自体の転圧や底部の遮水シートに よって雨水浸透や浸出水の流出を防止する構造になって いる. 品川ら $(2011)^{22)}$ は $50 \mathrm{~cm}$ 厚の砂質土層やローム層 による覆土のみでも浸出水の発生量を約 $1 / 4 \sim 1 / 20$ 程度 まで削減できることを示しており，覆土のみでも十分に遮 水効果が期待できるとしている. Igarashi et al. (2006) ${ }^{23)}$ は, シルト質土による覆土によって酸素消費率ベースでみた 硫化鉱物の酸化速度が $90 \%$ 以上抑制されることを示して いる。その一方で, 覆土の物性に加えて, 盛土構造物の 形状や気象条件等によって雨水浸透量は大きく変化する ことから ${ }^{24)}$ 遮水性覆土の設計・施工方法を構造安定性の 観点も含めて早期の確立することが求められる.

\section{$4 \cdot 3$ 不溶化処理の事例}

\section{(1) 不溶化処理技術の概要}

不溶化はセメントや薬剤等を混合することによって有 害物質を難溶性の形態や毒性の低い形態に物理的・化学 的に変化させる技術の総称であり，人為由来，自然由来 を問わず重金属等による污染に広く適用されている。自 然由来の重金属等を対象とした不溶化技術を原理の面か らみると，(1) 重金属類を特定の組成の低溶解度の化合物 へ転換する方法，(2)何らかの吸着体に吸着させる方法， の 2 つに大分することができる。 (1)の例としては，鉛や カドミウムを溶解度の低い硫化物態に転換させる方法が 挙げられる。一方(2)ついては，フェリハイドライト等 の酸化水酸化鉄鉱物への吸着, 自然の土畩中の酸化水酸 化鉄鉱物や腐植物質の吸着性を利用した方法が代表例と して挙げられる。また，直接的な不溶化ではないが，炭 酸カルシウム等のカルシウム系材料を添加することによっ て硫化鉱物等の酸性化を防止し，重金属等の溶出を間接 的に抑制する手法も適用されている. ${ }^{25)}$

添加する材料の観点からみると，(1) 硫化処理剤，還元
処理剂，キレート剂等の工業用化学薬剤, (2)硬化作用や イオン交換性，吸着作用等を有する鉱物種を主体とした 不溶化材，(3セメント等のカルシウム系材料，の3つに 大分することができる。特に，自然由来重金等への対応 においては，砒素の対応事例が多いことから，陰イオン にも対応可能な手法が採用されることが多い。また，(2) については天然の土壌材料も含有する鉱物や腐植物質に よっては吸着効果を有することが多いため, 比較的低コ ストでの対応が期待される.

\section{(2) 不溶化処理の検討事例}

近年報告されている自然由来の不溶化処理の検討事例 を表 6 にまとめる．現時点では，不溶化処理を大規模な 現場処理に適用した事例は比較的少なく，方法としても 従来のセメント処理が多い. その一因として, 不溶化処 理効果の長期安定性の評価事例や試験方法が限られてい ることが挙げられる。しかし，特に天然資材を利用した 技術の不溶化機構を考えると長期的な安定性が期待でき るものが比較的多いこと，覆土と併用することによって 長期安定性を阻害する外的要因の影響を抑制しうること 等を明らかにすることで，不溶化処理技術の信頼性向上 は四れると考えられる。

\section{$4 \cdot 4$ 反応層・遮水層による対策事例}

\section{（1） 反応層・遮水層による対策技術の概要}

反応層は掘削物から溶出した間隙水中の重金属等を捕 捉しうる材料やそのような材料を含有する層を盛土構造 物内や下部に構築することによって，溶出した重金属の 盛土構造物外への流出を防止する方法である。なお，既 往の文献ではこれらの工法を「吸着層」として示してい る場合が多いが，吸着以外の機構が作用している場合も あるので本稿では「反応層」と定義している，本技術は 水溶性の重金属を難溶性の形態に変化させるという原理 の面からは不溶化処理技術と同じであり，表 6 に示した 材料が利用されることも多い.

一方，遮水層は低透水性の材料を敷設することによっ て，流出水の流出量を抑制し，環境影響を抑制する。我 が国では遮水シートと集排水設備を併用することが多い が，雨水浸透を許容する場合には盛土の安定性からも集 排水設備の併用が必要である。一方，欧米ではベントナ イトと不織布から構成されるジオシンセティックスクレ イライナー (GCLs) を鉱涬保管施設の遮水層として適用 することを検討した事例が報告されている，GCLsの主 材料であるべントナイトはカチオン系の重金属に対して 吸着作用を発揮する効果も期待されるが，多価カチオン を含む浸出水によって GCLs が膨潤した場合や $\mathrm{pH}$ が 2 程度の酸性水に曝露された場合には透水係数が大幅に上 昇するので，適用にあたっては留意が必要である. ${ }^{32), 33)}$

表 6 主な不溶化材とその原理および検討事例

\begin{tabular}{|c|c|c|c|}
\hline 使用材料 & 原理 & 事例 & 文献の例 \\
\hline セメント系 & \begin{tabular}{|l|} 
難溶性化合物形成, 置換, 吸着, \\
物理的封じ込め
\end{tabular} & $\begin{array}{l}\text { 砒素, トンネル掘削ずり (片麻岩), 高炉セメント B 種 } \\
\text { 砒素, 粘性土系発生土, 高炉セメント B 種 } \\
\end{array}$ & $\begin{array}{l}\text { 和崎ら(2012) } \\
\text { 高井ら(2010) } \\
\text { 年) }\end{array}$ \\
\hline マグネシウム鉣物 & \begin{tabular}{|l|}
$\begin{array}{l}\text { 難溶性化合物形成, 置換, 吸着, } \\
\text { 物理的封じ込め }\end{array}$ \\
\end{tabular} & 吪素・セレン・フッ素, トンネル掘削ずり, 酸化マグネシウム & 大山ら $(2009)^{27)}$ \\
\hline カルシウム系材料 & \begin{tabular}{|l} 
難溶性化合物形成, 中性化, 物 \\
理的封じ込め
\end{tabular} & $\begin{array}{l}\text { 砒素，トンネル掘削ずり，炭酸カルシウム } \\
\text { 砒素，泥岩および頁岩，石膏（廃石膏を含む） } \\
\text { 砒素，泥岩，石灰系材料および石膏系材料 }\end{array}$ & $\begin{array}{l}\text { 佐藤ら }(2011)^{28)} \\
\text { 齋藤ら(2011) })^{29)} \\
\text { 井出ら(2009) }{ }^{30)}\end{array}$ \\
\hline 鉄塩系材料 & 難溶性化合物形成 & 砒素, 泥岩および頁岩 & 福武ら(2010) ${ }^{31)}$ \\
\hline
\end{tabular}




\section{（2）反応層・遮水層による対策技術の事例}

遮水層を用いた対策技術については従来から用いられ ており，表 2 中に示す遮水シートによる封じ込めの事例 を参照されたい。一方，欧米において検討されている GCLs の適用事例は国内では報告されていない。

反応層については, 表 6 に示す材料以外にも多数の検 討事例が報告されているが，我が国での報告事例が多い ものとしては，鉄鉱物系材料，天然土壌材料に大きく分 類できる．鉄鉱物は自然由来重金属等で最も超過事例が 多い砒素に対して効果的であり，検討事例は多い。鉄鉱 物といっても多種多様なものが適用されており，0 価鉄 粉のような工業製品, ${ }^{34)}$ 酸化物, ${ }^{35)}$ 低結晶性のフェリハイド ライト ${ }^{36)}$ やシュベルトマナイト ${ }^{37)}$ といった天然の鉱物ま で砒素やセレン等への適用性が広く報告されている。

一方，天然土堙材料については火山死 ${ }^{25)}$ や火山死質 土 $^{38)}$ が砒素の吸着性が高いことが報告されている。これ らの材料はアロフェンや腐植酸，鉄鉱物やアルミニウム 鉱物といった重金属類の吸着性の高い物質を含有してい ることによる。天然の土壌材料であることから，対策現 場の近傍でこのような土堙が入手できる場合には，特に 適用性が高いと考えられる。その一方で反応層の性能評 価方法については十分に確立されているとは言い難く， 試験時の固液比（バッチ吸着試験時），滞留時間（カラ 么吸着試験時), 浸出水中の共存物質, 化学的条件等に よって性能が大きく左右される. ${ }^{39)}$ 特に, 複雑な化学組成 を持つ浸出水中の共存物質の影響や重金属等の形態が性 能に及ぼす影響は大きいことから，実際の浸出水を用い て評価を行うことが重要である。

\section{5 結 言}

自然由来の重金属等を含む掘削物への対応においては, 盛土や地盤材料と改良材の混合といった基本的な土工や 地盤改良技術の果たす役割は大きい。今後は，環境安全 性の配慮に加えて，対策の合理性や工法自体の環境負荷 を考慮して対応を進めることが重要であり，本分野にお ける地盤改良技術の更なる開発と活用が期待される。

\section{参 考 文 献}

1) S. Hattori, T. Ohta and H. Kiya, "Engineering geological study on exudation of acid water from rock mucks Evaluation methods of rocks at the Hakkouda Tunnel near mine area”, Journal of the Japan Society of Engineering Geology, Vol.43, No.6, pp.359-371 (2003).

2 ) K. Okumura, K. Sakurai, N. Nakamura and Y. Morimoto, "Environmental impacts of naturally- occurring heavy metals and countermeasures”, Journal of Geology, Vol.116, No.6, pp.892-905 (2007).

3 ) K. Tanihata, M. Kikuya and Y. Takahashi, "Treatments and measures for contaminated muck caused by natural processes : Sendai City Subway Tozai Line”, Tunnels and Underground, Vol.41, No.1, pp.29-39 (2010).

4) T. Takahashi, K. Fujii, T. Igarashi, K. Kaketa and N. Yamada, "Distribution and leaching properties of arsenic in hydrothermally altered rock of Nakakoshi area, Central Hokkaido, Japan”, Journal of the Japan Society of Engineering Geology, Vol.52, No.2, pp.46-54 (2012).

5 ) K. Wasaki and M. Yamawaki, "Design and construction of geneisis including the heavy metal and pyrite in Shin Tomei Expressway”, Geotechnical Engineering Magazine, Vo.60, No.7, pp.10-13 (2012).

6 ) Technical Committee on the Countermeasures against Soils and Rocks Containing Natural-Derived Heavy Metals in Construction Works, "Technical manual on the countermeasures against soils and rocks containing natural-derived heavy metals in construction works (draft)", p.10 (2010) Ministry of Land, Infrastructure, Transport and Tourism, Japan.

7 ) F. W. Clarke and H. S. Washington, "Composition of the earth's crust”, U. S. Geological Survey Professional Paper, No.127, pp.1-117 (1924).

8 ) S. Yamamura, "World concern about arsenic in drinking water and WHO's response”, Journal of Groundwater Hydrology, Vol.42, No.4, pp.315-328 (2000).

9) Environmental Management Bureau, Ministry of the Environment, Japan, "Results of monitoring groundwater quality for fiscal 2010”, http://www.env.go.jp/water/chikasui/index.html, (2011).

10) S. Shima, M. Imada, T. Kimura, Y. Isono, N. Ikawa and Y. Yamamoto, "The distribution characteristics of the heavy metal which exists in the geological feature", Proceedings of 15th Symposium on Soil and Groundwater Contamination and Remediation, pp.546-551 (2009) Geo-Environmental Protection Center (GEPC).

11) H. Ito, "Case histories and leaching characteristics of natural-derived arsenic", Proceedings of Symposium on Groundwater and Geo-environment 2008, pp.87-98 (2008) The Research Committee of Groundwater and Geo-environment.

12) K. Fuji, M. Ishida, T. Yoshitake, T. Okeya, K. Kaketa and N. Yamada, "Case history on the countermeasure against arsenic contaminated ground", Proceedings of 11th Symposium on Soil and Groundwater Contamination and Remediation, No.S2-9 (2005) GEPC.

13) H. Masuda, "Geochemical cycle of arsenic in the earth's surface and mechanisms of its pollution of groundwaters", Journal of Groundwater Hydrology, Vol.42, No.4, pp.295313 (2000).

14) H. Kondo, "The outline on arsenic pollution of the ground waters in the southern region of Fukuoka Prefecture", Journal of Japan Society on Water Environment, Vol.20, pp.438-442 (1997).

15) T. Tatsuhara, T. Inui and T. Katsumi, "Soil chemistry and physics : 6. Soil chemistry and physics related to heavy metals with natural origins", Geotechnical Engineering Magazine, Vol.59, No.2, pp.52-59 (2011).

16) A. Tessier, P. G. C. Campbell and M. Bisson, "Sequential extraction procedure for the speciation of paticulate trace metals", Analytical Chemistry, Vol.51, pp.844-851 (1979).

17) S. Wada, "Dynamics of heavy metals in soils", Global Environmental Research, Vol.15, No.1, pp.15-21 (2010).

18) Y. Oagawa, S. Masuda, K. Suto and C. Inoue, "The chemical states of non-anthropogenic heavy metals in sedimentary rocks and their effects on the dissolution behaviors", 
Proceedings of 18th Symposium on Soil and Groundwater Contamination and Remediation, pp.128-133 (2012) GEPC.

19) S. Tamoto, Y. Ito, S. Anan and K. Okazaki, "Conformation and dissolution characteristics of toxic heavy metals of weathering rock mucks", Proceedings of 15th Symposium on Soil and Groundwater Contamination and Remediation, pp.595-598 (2009) GEPC.

20) T. Inui, M. Katayama, T. Katsumi, A. Takai and M. Kamon, "Evaluating the long-term leaching characteristics of heavy metals in excavated rocks", Proceedings of 10th National Symposium on Ground Improvement, in printing (2012) JSMS.

21) R. N. Yong and C. N. Mulligan, "Natural attenuation of contaminants in soils", CRC Press (2003).

22) S. Shinagawa, K. Yasumoto, K. Asai, S. Nakagawa and Y. Sasaki, "Comparison of leaching characteristics of natural sourced heavy metals by difference of constructing methods of embankments", Proceedings of 46th Japan National Conference on Geotechnical Engineering, pp.2077-2088 (2011) Japanese Geotechnical Society (JGS).

23) T. Igarashi, R. Saito, M. Sarashina and K. Asakura, "Impoundment of excavated pyrite-bearing rock using silty-covering soil”, Clay Science, 12, Supplement 2, pp.143-148 (2006).

24) W. H. Albright, C. H. Benson and W. J. Waugh, "Water balance covers for waste containment : principles and Practice", American Society of Civil Engineers (2010).

25) T. Arima, T. Igarashi and T. Tatsuhara, "Combined bottom volcanic-ash adsorption layer and calcium carbonate system from disposing excavated rocks producing acidic leachate with toxic elements", Geo-Environmental Engineering 2011, pp.107-114 (2011).

26) A. Takai, J. Hishikawa, S. Yamakawa, K. Mori, K. Konishi and H. Kojima, "Insolubilization effect in granule process of cohesive soil containing heavy metals”, Proceedings of 16th Symposium on Soil and Groundwater Contamination and Remediation, pp.249-252 (2010) GEPC.

27) S. Oyama and Y. Hoga, "Application of solidification/ stabilization treatment with $\mathrm{MgO}$-based material for the soil which contain heavy metal or pollutant in the natural origin”, Proceedings of 15th Symposium on Soil and Groundwater Contamination and Remediation, pp.557-558 (2009) GEPC.

28) D. Sato and T. Igarashi, "An occurrence of acid water containing heavy metals like arsenic from excavated rocks and its countermeasure”, Proceedings of 17th Symposium on Soil and Groundwater Contamination and Remediation, pp.137-141 (2011) GEPC.

29) K. Saito, E. Uematsu, H. Tamura and S. Tsunematsu,
"Insolubilization of arsenic in soils of natural origin by adding gypsum powder-Solubility of calcium arsenate in the presence of gypsum-" The 51st Technical Report Conference (2011) Hokkaido Branch of Japanese Geotechnical Society.

30) K. Ide, H. Kubo, T. Miura and T. Higasayama, "Examination of arsenic insolubilization materials for landfill condition”, Proceedings of 44th Japan National Conf. on Geotechnical Engineering, pp.1855-1856 (2009) JGS.

31) K. Fukutake, K. Ide and T. Higasayama, "Examples of insoluble arsenic-contaminated soil by naturally-occurring”, Proceedings of 16th Symposium on Soil and Groundwater Contamination and Remediation, pp.131-135 (2010) GEPC.

32) C. D. Shackelford, G. W. Sevick and G. R. Eykholt, "Hydraulic conductivity of geosynthetic clay liners to tailings impoundment solutions", Geotextiles and Geomembranes, Vol.28, pp.149-162 (2010).

33) A. Naka, Z. Li, T. Inui, T. Katsumi and H. Mogami, "Heavy metals retention in geosynthetic clay liners and its potential role in acid rock drainage treatment”, Geosynthetics Engineering Journal, Vol.25, pp.233-240 (2010).

34) M.A. Abedin, T. Katsumi, T. Inui and M. Kamon, "Arsenic removal from naturally contaminated groundwater by zero valent iron : A mechanistic and long-term performance study”, Soils and Foundations, Vol.51, No.3, pp.369-377 (2011).

35) M. Doko and Y. Hirai, "Consideration of Se(VI) treatment method by iron oxide material”, Proceedings of 17th Symposium on Soil and Groundwater Contamination and Remediation, pp.233-237 (2011) GEPC.

36) K. Marumo, "Remediation of geological contamination with minerals”, Resource and Environmental Geology, The Society of Resource Geology, pp.393-398 (2003).

37) K. Ito, H. Ikeda, T. Tatsuhara, S. Naohara, T. Sato and T. Kawanishi, "Evaluating percolation and insolubilization characteristics of arsenic in schwertmannite-amended soil”, Proceedings of 12nd Symposium on Soil and Groundwater Contamination and Remediation, pp.541-545 (2006) GEPC.

38) S. Tani, S. Uehara, Y. Kibota, T. Miura, T. Takahashi and N. Uchida "Adsorption characteristics of stabilization materials for arsenic-polluted soil (3)”, Proceedings of 45th Japan National Conference on Geotechnical Engineering, pp.1957-1958 (2010) JGS.

39) E. Uematsu, M. Narita, T. Koguchi and S. Tsunematsu, "Notes on the conditions for evaluating the performance of absorbents", Proceedings of 18th Symposium on Soil and Groundwater Contamination and Remediation, pp.78-83 (2012) GEPC. 